\title{
SOME DATA CONCERNING THE HISTORY OF PHYTO- PATHOLOGY IN BRAZIL AND THE FIRST NOTICES OF DISEASES OF PLANTS IN THE COUNTRY*
}

\author{
By Dr. Arsinne Puttemans
}

(Translated by Anna E. Jenkins, Bureau of Plant Industry, U. S. Department of Agriculture, and Annie D'Armond Marchant, Pan American

Union, Washington, D. C.)

It may seem premature to discuss the history of phytopathology in Brazil, seeing that up to a short time ago this science has received little or no attention from the Government or the thinking people in our country.

This, however, is natural when we consider that this science is relatively new; that our agriculturists are few in number, and their scientific preparation generally deficient and that the economic importance of applied phytopathology and agricultural entomology has not been duly recognized by our Government.

In our defense, however, we may not only indicate various countries of older civilization and evolution than ours who have not done for the protection of their agriculture what we have done in recent years, but also the increasing number of young people who are now interested in these studies, and who represent for the near future a nucleus of specialists from whom we have every reason to expect the greatest good for our national agriculture.

My only purpose in speaking to you today of the history of phytopathology is that of bringing to you my modest contribution in Brazil. This seems to be justified by my forty years' devotion to the seience, by the observations and original investigations which I have been able to accomplish through my association or contacts with some of the pioneers, as well as by my own modest activity in the diffusion of this work, as professor, publicist, and above all, as organizer and first chief of the service of phytopathology of the Ministry of Agriculture. From this service sprang our present Federal and State phytopathological services and in part our already most efficient Plant Quarantine.

However, before detailing these facts, permit me to explain to you my conception of the history of phytopathology in Brazil, because from such comprehension helpful suggestions which might otherwise be over-

\footnotetext{
- Contribution presented at the General Session, Janury 22-23, 1036, of the First Meeting of the Phytopathologists of Brazil [Primeirs Reuniño de Phytopathologistns do Brasill Rio de Janeiro, 1930 (Rodriguesia 2 (numero especial): 17-36. 1936 (1937)).
} 
looked may perhaps be derived for the guidance of our young colleagues in their observations and deductions.

Following are the principal points which might be covered in such a history:

(a) The sketches of the lives of scientists of the old and new generation, whether nationals or foreigners, both in and out of this country, who are engaged with the diseases of our plants, both wild and cultivated.

(b) The advancement of our lonowledge of this science, with mention of original works on discoveries or investigations relative to phytopathology in general or in particular. This point should include also a comparison of lists of diseases published periodically, and organized in so far as possible, by geographic or agricultural zones and seasons, and in reference to specified periods of time.

(c) The date of the first appearance or observation, communication or introduction of the diseases of our principal cultivated or useful plants; the particulars of their dissemination in the country; the eventual phases of the re-appearance, intensification or periodicity of such diseases; the control methods adopted; the results obtained; the eventual damages and their economic consequences to the country.

(d) The establishment and development of the study of phytopathology in the country, the first courses organized, their relative importance, their programs in the various schools, the diffusion and nature of this teaching, whether by free courses, or specialization for agriculturalists and the extension work among the farmers or by means of pamphlets, journals and magazines, lectures, practical demonstrations, meetings, or congresses of phytopathologists, ete.

(e) The creation of official state and federal services, their development, the protection of plant health, control in the fields, quarantines, the chronological facts of the methods adopted, etc.

(f) Discussion of bibliography, giving the enumeration and locality of specific works found in our public or private libraries; and also of the mycological and phytopathological herbaria deposited in our country as well as in foreign countries, but always with relation to the flora of Brazil.

These propositions might be improved upon both as to grouping and expansion. However, for the present, they may serve to guide those who are in a position to render valuable contributions to the history of phytopathology in Brazil through the collection of authentic data.

For my part, I wish only to record here some facts of a certain period of our phytopathology, citing particular cases and fixing some points 
relative to the first appearance or record of some of the more important diseases of our cultivated plants.

However, first of all I wish to emphasize the necessity for clearing a controversial point, that is, the distinction that must necessarily be established between mycology and phytopathology.

Mycology, properly speaking, is limited exclusively to the study of fungi, of all the fungi, the largest as well as the microscopic, as much from the point of view of pure science as from that of practical applications; the maling of fermented drinks, of bread, of cheese, etc.; the use for human consumption of native or imported fungi or mushrooms, either wild or cultivated, a subject as yet almost completely negleeted among us; diseases of man and domestic animals caused by parasitic fungi, and, finally, the large number of plant diseases also eaused by fungi, a subject which constitutes one of the most important branches of phytopathology.

I repeat, "one of the most important branches of phytopathology," for I cannot agree with the definition of this science given incidentally in the inaugural session of this Meeting by our illustrious colleague, Rev. Padre J. Rick, who considers phytopathology as merely a branch of mycology, or mycology applied to diseases of plants.

In truth, that opinion might have been acceptable at a time when parasitic fungi caused nearly all the plant diseases which were known; today, however, phytopathology represents a well-defined science embracing besides the parasitic diseases, the study of traumatism in general and all the physiological disturbances which threaten the life of the plant or its normal development.

It is conceivable, then, that in order to fulfill this program, phytopathology must utilize information obtained from other sciences, such as, besides mycology proper, anatomy and plant physiology; physical geography; or, in other words, ecology; systematic botany, not only with reference to parasitic or saphrophytic species, but also to the systematics of the phanerogams which is indispensable to the identification of the great majority of parasitic fungi; chemistry and physics, as important factors of the life of the plants, both parasites and hosts, and likewise necessary in the study, preparation and application of the remedies or methods of control; general and special agriculture; the processes of which frequently determine or exercise direct influence on the sanitary condition of cultivated plants; zoology, more especially as related to certain causal worms, or mites that produce plant diseases and which are conventionally united with phytopathology, in addition to which this science, together with meteorology also furnishes 
information of the processes and causes of transmission, diffusion or intensification of many plant diseases; microscopy and technique of laboratory investigations indispensable to modern research in plant biology; bacteriology, which today forms a most important chapter of phytopathology; and, finally, the question of filterable virus, the nature of which is still unknown, but which has opened a new field of study for phytopathologists.

We see by this enumeration, which I do not present as being complete, that mycology represents only one of the branches of knowledge necessary to phytopathologists in general, and it can even be dispensed with by restricted specialists, such as those who devote themselves exclusively to physiological diseases, to bacterial diseases or to the filterable virus diseases. On the other hand, an expert systematic mycologist of the higher fungi may perfectly well remain an entire stranger to the many subjects I have enumerated.

It is a pleasure to render here the homage and tribute of gratitude of the phytopathologists to those jllustrious and self-sacrificing mycologists, eollectors of Brazilian fungi: Glaziou, Puiggari, Ule, Moeller, Hubert, Rick, Usteri, Torrend, etc., as well as to the descriptive botanists: Spegazzini, Hennings, Theissen, Sydow, Hoehnel, to mention only the most notable, and confining my references to the period which embraces the latter part of the past century and the first part of the present $(1920)^{1}$.*

It is indeed true that the interest of the majority of these soientists was limited almost exclusively to systematic knowledge of the species, to the constitution of the mycological flora of Brazil without further preoccupation with the parasitic action which many of them exercise.

Personally I have known and corresponded with the majority of the scientists referred to above. Among them, however, I wish especially to call to your attention, Puiggari, a unique type of scholar, whose existence remained unknown for many years to our Government and to our intellectual elite.

Juan Ignacio Puiggari was one of the greatest collectors of cryptogamic plants of Brazil; physieian of the University of Barcelona, he came to Brazil in 1877, remained for a long time, that is until 1892, in Apiahy (73), a little place, lost in the midst of the woods of the southern part of the State of S̃̃o Paulo. There he made all his collections, living exclusively dedicated to his chosen science, without other ambition than to study the lower plants which he collected in his constant excursions about Apiahy. ${ }^{2}$

\footnotetext{
"Numbers in parenthegis refer to "Literature Cited", page 102, and numbers in small type to "Addends", page 96.
} 
Puiggari and I were co-workers in the Botanical Section of the Geographical and Geological Commission of the State of São Paulo, where he was engaged for the position by the director, Alberto Loefgren, ${ }^{3}$ and recalling that time $I$ remember this brilliant but humble scholar as being of small stature and frail physique, yet to get an idea of the untiring energy of this pioneer student and investigator of cryptogams, it is sufficient to recall that with regard to our fungi, Spegazzini (90) in his work "Fungi Puiggariani" mentions nearly five hundred species, most of which were considered new to the science.

However, as we have already seen, the interest of Puiggari was not limited to fungi, for it included all the cryptogams; in fact, the lichens and mosses collected by him have occupied the attention of many illustrious European specialists with whom he corresponded and exchanged herbarium specimens. Among them may be cited: Hampe, Broterius, Müller d'Argovie, Hildebrand, Duby, etc. Puiggari died in São Paulo in 1900 at the age of seventy-seven years.

I do not know in what museums are actually to be found the types and co-types of the material studied by Puiggari and by him sent to his correspondents, except that part of his fungi may perhaps be found in the Museum Spegazzini in La Plata (Argentina). However, for those who may be interested, I am glad to state that in my private herbarium I possess not only specimens of fungi sent to me many years ago by my deceased friend, Dr. Ignacio Puiggari $J_{r .}$, but I also bought from his widow all that remained or that it was possible to salvage from the Puiggari collections, which, though damaged by lack of proper care, still represented scientific material of the greatest value. ${ }^{4}$

We will now consider Brazilian phytopathology itself or rather the seientific observations taking place among us with especial emphasis on the losses to the cultivated plants and their economic consequences. In this respect I believe I can attribute the first place both in date and importance to F. M. Draenert, who upon arriving from Germany, in 1863 , in Bahia, had there the opportunity while residing on a great sugar cane plantation, to study a dangerous disease which was then devastating the erop.

The observations of Draenert were published in German in a technical journal, "Zeitschrift für Parasitenkunde" (Jena, 1869) under the title: "Weitere Notizen uber die Krankheit des Zuckerrohrs," (21) and were translated into Portuguese in the "Jornal da Bahia," number 4934, in January 1870.

This work of Draenert not only marks an epoch in scientific publieation on diseases of plants in Brazil, but likewise represents the first report in the world of a bacterial disease of plants. In fact, the works 
of Burrill $(88,103)^{6}$ and Prillieux $(72,88)$ date from 1878 to 1879 , as shown by the publications of both, and they deal respectively with bacteria of pear and of wheat.

The fact that a bacterial disease of plants was recorded here in Brazil about ten years before the date generally attributed to this discovery in modern phytopathological treatises, appears to me to be of the greatest importance in view of the right to priority of Draenert and of Brazil. One of his biographers represents this scientist as having been unhappy during his life time, şuffering great disappointment and even injustice, although he was accorded great esteem for all his scientific achievements connected with agriculture.

The bacterial organism found in Bahia by Draenert must have been Pseudomonas vascularum (Cobb) E. F. Sm.

In discussing the diseases of sugar cane, it is well to remember also the works of A. Krauss, chemist of the Imperial Botanical Garden [Rio de Janeiro] which were carried out in Bahia from 1876, i.e., seven years after those of Draenert; and also those of the Committee appointed in 1879 to study the disease called Mal Vermelho (Red Disease) which at that time was ravaging the sugar cane plantations of the Province of Pernambuco. The outstanding personality of this commiltee seems to have been Dr. Sá Pereira, who was especially in charge of microscopic studies. This illustrious physician presented in 1880 an extensive report on the work that he had accomplished. Although he had not succeeded in determining exactly the systematic position of the organism that caused the disease, he recognized its parasitic character, agreeing in part with the conclusions of Draenert, but disagreeing as to the micyoscopic data, admitting, however: "My knowledge of the microscopy of plants is very limited."

Perhaps it was not a case of just one disease both in Bahia and in Pernambuco, and I suspect that Colletotrichum falcatum Went. was even then associated with the bacteriose, thus rendering difficult the task of the scientists of that time.

The concrete facts, however, resulting from the scientific investigations were: First, the recognition of the parasitic nature of the disease, an opinion opposed by many "authorities" of the period; second, the useful knorvledge given to the farmers on methods of controlling and avoiding as much as possible this terrible disease.

In addition to sugar cane, from 1870 on, another plant of great economic value, coffee, was attacked by a disease or pest which continued to encroach upon the coffee plantations of the then Province of Rio de Janeiro, causing the growers great and warranted apprehension. The 
first study of scientific nature carried out among us on the abovementioned disease, appears to have been that by the French zoologist, C. Jobert, whose study was reported in the "Comptes Rendus de l'Académie des Sciences" in 1878 (48), a fact which in itself shows the importance and value of this work.

Jobert proved without a doubt that the disease in question was caused by an anguilluta or nematode, an opinion verified by $\mathrm{E}$. Goeldi, 7 who was commissioned in 1886 by the Director of the National Museum to carry out a detailed study of the disease. In his report of 1887 (30), this scientist- who gave the nematode of coffee the name of Meloidogyne exigua, which was afterward shown to be only a synonym of the cosmopolitan species, Heterodera radicicola, today called Caconema radicicola-expressed himself as follows relative to the work of Jobert:

"Mr. Jobert was the first and the only one of my predecessors who searched for a solution of the question of the disease of the coffee tree in the biological field, and recognized from the beginning the necessity of resorting to the microscope as a most important aid. His note reveals also the professional biologist, master of his subject and proficient in the use of the instrument to which modern scientists owe so many and such valiant conquests."

In this same report of Goeldi, we should observe the notice of the brown leaf spot of coffee caused by a parasitic fungus improperly named by A. Baglioni, in 1878, "Eresipho do Cafeeiro" and, in 1902, by Gustavo Dutra, "molesiia dos olhos pardos"s (Brown eye spot).

Goeldi considered this disease as without importance to the coffee tree and as being caused by Ramularia, ${ }^{9}$ which he did not specify, but which in 1902 was named Ramularia Goeldiana, by the illustrious mycologist Saccardo on the basis of Goeldi's description and figures. It is today established that Ramularia Goeldiana does not differ at all from Cercospora coffeicola, a species created in 1881 by Berkeley and Curtis from material collected in Jamaica.

The reason which prompts me to mention these facts is not only the wish to call to your attention a question of priority in the recognition of a parasite which, incidentally, was unknown in the country of the origin of the host plant, but, above all, to point out to you Goeldi's drawings as constituting the first microscopic illustrations [Plate IV] published in Brazil relative to a plant disease.

These figures, nevertheless, show clearly to the eye of a specialist, that Goeldi, although a scientist of high esteem, was not a mycologist and that he accepted the graphic interpretation of his artist AveLallemand, an excellent man, who was my companion in work in the 
Geographical and Geological Commission of São Paulo from 1885 (sic). ${ }^{10}$ The above mentioned drawings clearly show the difficulties encountered by an excellent artist in interpreting correctly the microscopic figures of scientific subjects, the peculiarities of which are unknown to him. In the case in question we see the mesophyll tissue of a transverse section of a leaf of caffee plant as if it were a wall of bricks regularly arranged and without any intercellular spaces, and we see the conidia of the fungus apparently protruding from the stomata instead of forming at the extremity of the conidiophores.

In 1888 Goeldi was again commissioned to study the pests and diseases of the grapevine, more especially the Phylloxera, in the Province of São Paulo. As this subject pertains to entomology $I$ would not refer to it here if it were not for the fungus diseases with which it deals. Goeldi (29) declared in 1889 that he had found no reference to Plasmopara (Peronospora) viticola or downy mildew, nor had he heard it mentioned by viticulturists of São Paulo. He does refer to the existence of Oidium Tuckeri (Uncinula necator (Schweinitz) Burr.) and of the "anthracnose"11 (Elsinoë viticota Racib., conidial stage, Sphaceloma ampelinum de By). ${ }^{12}$ It is worthy of note, however, that he does not mention Cercospora viticola (Ces.) Sacc. which I found abundantly on the grape (Isabella) both in Petropolis in 1892, when I first came to Brazil, and also in São Paulo and Piracicaba in 1894.

I quote here an excerpt from the report of Goeldi on the two fungus diseases which he reported in 1889 on grapes:

"The moment a grape vine is found to be attacked by anthracnose or by Oidium Tuckeri, the irrigation pump with Bordeaux mixture or a solution of copper sulphate should be employed at once. Let us hope that such a useful utensil will not be lacking to the Brazilian viticulturist, and that very soon the nature of such fungus enemies will be generally known! The good resuits will not be slow in appearing!"

Excellent advice, except that it is not with an irrigation pump that the fungicide is sprayed and that in the case of powdery mildew the use of sulphur and its derivatives would perhaps be more advisable.

The account of the works of 'Draenert, Krauss, SE Pereira, Jobert, Goeldi, etc., shows us that these subjects of phytopathology with the scientific aspect indispensable to such studies, were not totally unknown in Brazil over half a century ago; they were, however, treated in a sporadic fashion, as it were, or rather by naturalists, of great merit certainly, but not really specialists in the subject, which they approached with general knowledge and not infrequently for the first time, without the practice and experience of the true specialist.

The first official position of phytopathologist in Brazil seems to have 
been created in 1888 by Dafert, the learned director of the Agronomical Institute of Campinas, in the State of São Paulo. However, the place remained vacant until 1893, when it was occupied by the German Dr. Franz Benecke, whom I mention here merely as having been the first phytopathologist in title, for he held the place only a short time and did not accomplish much of value. On the contrary he sometimes gave the farmers wrong advice. Thus, for example, relative to sooty mold of coffee, he (See 18, pp. 320-321) gave the following advice: "Burn at once all the diseased parts in the locality of infection in order to avoid propagation by transportation."

This advice was very strange for a specialist because at that time the relation was perfectly well known between sooty mold and plant lice which are the actual cause of the trouble and its spread. It was likewise Benecke (18, pp. 320-321) who in the report of the abovementioned institute with regard to the disease of potatoes caused by mildew (Phytophthora devastatrix (Lib.) Puttem.) ${ }^{13}$ asserted that there was no cure for the disease, "since the fungus lives inside the plant all external treatments would be useless."

Thus he showed that he was completely ignorant of the publications of Jouet (1885), Prillieux (1886 and 1888), Aimé Girard (1890), ete., telling of the great efficiency of Bordeaux and other mixtures in the treatment of this disease, treatment without which the eulture of potatoes was, and still is, in Brazil one of the most disheartening.

It seems to me interesting to cite here, relative to the state of phytopathology at the end of the last century, that which Dafert said in his report of 1896 (Volume VIII, page 319) (18):

"Our phytopathological and entomological services, both of which are of great importance to agriculture, progressed but little in the years 1894 and 1895 , owing to the fact that it had not yet been possible to find suitable specialists for places which have been vacant for years. The place of phytopathologist was filled for a short time and that of entomologist was never filled. We have, however, to find eventually the people whom we need, and with the enlargement of the buildings of the Institute, the conditions for a fruitful activity of the new sections pill also be increased."

The phytopathologist whom Dafert was awaiting was Fritz Noack, who lived in Campinas from 1896 to 1898 and to whom we owe valuable works, among them descriptions of twenty-three of our plant diseases, published in the Agricultural Bulletin of the State of São Paulo in 1898, under the title "Phytopathogenic fungi of orchards and gardens." (Boletion de Agricultura do Estado de São Paulo, 1898) (62).14

Noack, who like his countryman Draenert, was tall of stature, with 
blue eyes and a light beard, was quiet and kindly in temperament. He prepared at least two pupils in Brazil-one, the vealthy coffee planter of Campinas, Dr. José de Campos Novaes, an amateur naturalist whom Noack assisted in the publicetion of an excellent monograph ${ }^{15}$ in the vernacular concerning diseases of grapes, illustrated with excellent color engravings. Unfortunately, upon the return of Noack to Germany in 1898, Campos Novaes lost his guide and teacher, and, although he remained for many years at the Institute as phytopathologist, and although he collected a valuable private scientific library, yet never again did he produce anything of value on the subject in which he considered himself a specialist. He died a few years ago in Campinas, where he had lived, it appears, in great want, spending the greater part of his salary in buying books.

The other pupil of Noack to whom I referred awhile ago was myself. However, though I called myself Noack's pupil, I never really worked with him or sought his advice or direction. In fact it was only after his return to Germany that I began to dedicate myself to the subject. However, during our frequent and most cordial contacts-both on the occasion of his visits to the Botanical Garden at Cantareira, where I was then working under the supervision of Alberto Loefgren, and during a botanical excursion of over a month in the Serra da Mantiqueirathe activities of Noack, which I had the opportunity of vitnessing, and our conversations revived my early interest in phytopathology, the elements of which $I$ had learned with the eminent Belgian botanist Emile Laurent, who was kind enough to consider me his favorite pupil.

This resulted on my part in a great desire to possess a microscope and literature of my own, which would permit me to spend my spare time in the study of this science, which so fascinated me and to which I really owe the greatest intellectual satisfaction of my life. Indeed, the pleasure of discovery or even the simple confirmation of problems or the most infinitesimal biological observations, repay abundantly any effort put forth or difficuities encountered. Such difficulties in fact were inevitable in the case of a mycologist or phytopathologist, working as I did at that time, alone and far from scientific centers and deprived of the incentive and assistance of colleagues or masters.

In his report of the Botanical Section of the Geographical and Geological Commission of São Paulo in 1898 (sic) ${ }^{16}$, my chief Alberto Loefgren (51) wrote:

"As the knowledge of plant diseases is of great importance for their perfect control, especially in countries like Brazil, where these studies are still young, and owing also to the fact that the phytopathologist of the Agronomical Institute, Dr. Noack, has gone away, the Horto Bo- 
tanico started to collect all cases of diseases found. The assistant of this Horto, Mr. A. Puttemans, has been in charge of these studies, the results of which we are giving in resume. When he has the opportunity he will present them separately with diagnoses and plates.

"The total number in the phytopathological collection amounts to 415 species, found in the Horto and surroundings."

"Following is a list of the species most harmful and those to which most attention has been given, together with the hosts on which they were collected":

The above-smentioned list contained 54 parasites of cultivated plants, classified by me. This constituted my first contribution to the knowledge of our plant diseases. I must say that I never found in Loefgren any real assistance with these studies. The microscopic work was nearly always done by me with artificial light (kerosene lamp), in my private room in hours out of schedule.

I hope to be excused for these personal details but as I am writing of the history of phytopathology in Brazil, with which I was identified by the force of circumstances, I consider it more advisable to furnish first hand the data regarding myself.

What disposition Loefgren made of the collection mentioned above I do not know. But I believe that it was incorporated in the Herbarium of the State, probably now with another that I sent later. In any case the first 57 numbers of this collection, I sent for verification through Loefgren to Noack, who was then again professor in Darmstadt. Unfortunately, I waited in vain for an answer, the lack of which I attributed to the fact that Noack was already suffering from the illness from which he died a few years later. I decided then, on the advice of my good friend and colleague, Dr. Gustavo Edwall, ${ }^{17}$ a retired Swedish botanist, of the Department of Agriculture of the State of São Paulo, to send my collections to the Museum of Berlin. There the specialist Paul Hennings, during the period between 1902-1908, described in "Hedwigia" (37) as many as seven genera and 205 species new to science from the material collected by me in São Paulo during the jears 1900-1904. ${ }^{18}$

Specimens of my collections-co-types-were sent to the Museum of Berlin, where they were studied first by Hennings, then by Sydow and Theissen; and to the Museum of Vienna where they were made use of by Hoehnel, for his critical studies published in his "Fragmente zur Mylsologie" in which he confirmed (39) the genus Puttemansia, created by Hennings (37, I), ${ }^{10}$ and enhanced its values with the creation of new species. Other co-types of my collection are found in the Botanical Garden of Brussels and in the herbarium of the Plant Pathological Service of Paris; in Brazil, as I have already mentioned, co-types 
are found in the Herbarium of the State of São Paulo, in the Institute of Plant Biology of Rio de Janeiro.20 I also gave a valuable collection to the Escola de Agricultura "Luiz de Queiroz" in Piracicaba, at the time that I was professor there. This collection disappeared mysteriously according to a communication which I received at that time from the Director, who, if I am not mistaken, was Dr. Leonidas Damasio. This proves again how wise it is "not to put all your eggs in one basket," or in other words to distribute your co-types as much as possible in various places. ${ }^{21}$

I would like to tell you something now about the teaching of Phytopathology, concerning which I can speak with authority only in regard to the State of São Paulo. In the general course for Agricultural Engineers of the Polytechnical Sehool, the classes of Plant Pathology, which were started, if I am not mistaken, by Garcia Redondo, professor of Botany, between 1893 and 1899, were continued later by Professor Arthur Thire up to 1901, when they became a part of the course of Special Agriculture taught by my brother Hubert Puttemans, agricultural engineer, until the end of 1903, when I assumed charge of the class both in the theoretical as well as the practical part. My teaching terminated in 1910, when I left for Rio de Janeiro, where I had just been appointed Chief of the Phytopathological Laboratory of the National Museum.

Ever since the Agricultural College was founded at Piracicaba in 1901,22 as I recall, phytopathology was a part of the course in botany, to which the subject of agricultural microbiology was also added. It seems to me that from the beginning the professor of this subject was the unfortunate Dr. Germano Vert, who committed suicide in 1908, if my memory does not play me false.

I do not like to criticize my colleagues, especially after they are dead. I cannot, however, neglect to point out their questionable qualifications in phytopathology, owing to the necessity of contradicting their affirmation regarding the existence in 1905 of Anthracnose on cotton (GTomerella gossypii (South.) Edg. in the form of Gloeosporium) in the cotton fields of Piracicaba.

In fact, it was in this year that Germano Vert published his observations in the "Boletim de Agricultura" of São Paulo, and it was in the same year that, as a matter of verification, I went through the cotton fields many times without ever finding the above-mentioned parasite. I should add that for some years I had been especially interested in the diseases of this plant. In 1905, at a meeting of the Sociedado Scientifica de São Paulo, commemorating the death of Tinnaeus, I pointed out the existence in Brazil of the bacteriose of the leaves and boll 
(Pseudomonas malvacearum Smith) and the part played by Dysdercus in its propagation. I should say that $I$ also had in my herbarium the specimens of "anthraenose" sent to me by the distinguished creator - of this species, the North-American, Professor Atkinson. These specimens would have facilitated the exact identification of the parasite in case I had found it.

As a matter of fact Germano Vert, in spite of my requests made officially by registered mail, never favored me with specimens of the parasite identified by him. The following quotation will give us some idea of the confidence to be placed in this author's work.

"The bad condition of the microscopes available and the lack of a microtome made the investigation somewhat difficult, particularly in view of the fact that the high temperature and alternate periods of torrential rains and hot sun prevented completely the exterior manifestations of vegetation and fructification from developing its normal aspect. Finally after long weeks of study, an apple culture grown in a moist chamber caused the appearance of characteristic masses of conidia which enabled me to identify the plant."

The spots on the boll that Germano Vert attributed to an anthracnose were due principally to bacteria or perhaps in some cases to Cercospora gossypina Cke., which was very common at that time in Piracicaba. In the case of bacteria it is easy to explain the great difficulties encountered by Germano Vert in finding the conidia of Gloeosporium, which he sought so assiduously. As to the conidia found in the moist chamber, doubtless they belonged to some saprophyte which aceidentally developed there.

Another example of Germano Vert's deficiency in phytopathology was the fact that he objected to the use of cut bamboos for fences, sta,kes, lattices, etc. on the farms, believing them to be responsible for the propagation of sooty mold. This showed that he was not only completely ignorant of the very special biologioal conditions connected with the development of sooty mold, but also that he had never examined microseopically the black covering sometimes found in the cut bamboos, which is due to various saprophytic fungi entirely different from those found in the sooty mold, for example, of Helicoma bambusae P. Henn. which has very characteristic curved conidia.

My insistence on the absence of anthraenose of the eotton plant in the State of Säo Paulo from 1905 to 1913 applies only to that period, as subsequently the disease was found, I believe, in the State of Minas Geraes, as may be proved by specimens existing, for instance, in the Herbarium of the Institute of Plant Biology. ${ }^{20}$

After Germano Vert, the professors that were in charge of the classes 
in phytopathology at Piracicaba were in chronological order: Dias Martias, Arthaut Berthet, Charropin, who died during the World War, and Averna Saccá, who was appointed while in Italy by the Government of the State of São Paulo and who became a more notable professor of phytopathology than of botany.

We should not proceed, however, without mentioning the work in phytopathology of Dr. Averna Saccá, who although a prolific author, produced nothing which could be accepted with assurance. This was not so much due to exrors contained in his publications, for some of his works might be expurgated and used with a certain amount of care expended upon them, but principally due to his unscientific dealing with the subject matter and to the innumerable scientific impostures found in his works, which are absolutely undeserving of confidence even from the most charitable critic. Moreover, it is sufficient to say that the numerous new species ereated by Averna Saccá are not supported by herbarium specimens deposited in scientific institutions, or distributed, so far as I know, to private seientists, and also that these new species were not taken into consideration by Saccardo who does not mention them in his "Sylloge Fungorum," which is a general index of world mycology.

I do not wish to enter into a discussion of the more modern phase of phytopathology in Brazil, ${ }^{23}$ as I might make omissions due to forgetfulness or ignorance of the facts; therefore I shall not refer to the professors from Piracicaba or other schools after 1920; however, I shall not deny myself the pleasure of registering bere the great regard which I have for some of them.

I wish, however, to bring to attention also the noted Brazilian agriculturist Gustaro Dutra, who for many years was director of the Agricultural Institute in Campinas, and who published numerous monographs on our cultivated plants with frequent descriptions of diseases affecting them. Unfortunately these descriptions show lack of specialization in the subject.

Therefore it is only with great reservations that we can accept the existence in the coffee fields of São Paulo of Armillaria mellea (Vohl.) ex Fr. as well as other diseases reported by G. Dutra. Indeed we could say the same in regard to many plant parasites indicated in Brazil by authors whose assertions were based exclusively on foreign literature or on macroseopic analogies without due confirmations through microscopic examinations or by specialists.

This is the reason why the notification of diseases, which can not be verified by duly preserved material accessible to specialists, is always subject to dispute, especially if the sponsors are not recognized authorities in the subject. 
In 1906 I published in the Yearbook of the Polytechnical School of São Paulo a second list of diseases of our cultivated plants, also collected in São Paulo, and in which I enumerated a hundred species, many of which were reported in the country for the furst time (76).

I shall limit myself to a few brief references to the publications of J. Rick of the State of Rio Grande do Sul, whose first list (84), if I am not mistaken, was published in 1908 (sic) ${ }^{24}$, as they treat exclusively of mycology, though some of the species mentioned are plant parasites (85).

In 1910, a quarter of a century ago, through the influence of the late agriculturist, Sergio de Carvalho, the then Secretary of Agriculture, Dr. Rodolpho de Miranda, organized under the National Museum, three new independent laboratories devoted exclusively to the study of phytopathology, agricultural entomology, and agricultural chemistry.

I had the honor to be appointed by the Minister to organize and direct this first laboratory of phytopathology. At the same time Eugenio Rangel was appointed to be my assistant.

In my first report, submitted in 1910 to Dr. J. B. de Lacerda, then Director of the Museum, I mentioned among other diseases of our plants, that of the inflorescence of the cauliflower, caused by Alternaria brassicae Sacc., the first notice of which was contained in my article published in 1911 in the Bulletin of the Royal Society of Belgium (77). This disease was later found and described in the United States in 1924.25 Today this disease is considered to be quite destructive both in the United States and in Brazil. In 1934 the above mentioned report of 1910 was reproduced in "O Campo" with illustrations, under the title, "Ligeira contribuição a Phytopathologia Brasileira," (A small contribution to Brazilian phytopathology) (80)..$^{23}$

In 1912 I found it necessary for personal reasons to go to Furope, and resigned my position, which was filled by the eminent mycologist and phytopathologist André Maublane, who was engaged in France by Minister Pedro de Toledo on the recommendation of Eugenio Rangel. After two years, at the termination of Maublanc's contract, Rangel took over the work definitely and was in charge of the Service when it was transferred first to the Jardim Botanico and later in 1920 to the Biological Institute of Plant Protection (Instituto Biologico de Defesa Agricola), of which it became a section.

At this same time the Minister Simóes Lopes established a Section of Selection of Immune and Resistant Plants (Seç̧ão de Seleç̧ão de Plantas Immunes e Resistentes) in the Biological Institute the directorship of which was offered to me by the Minister-by telegram, as I was then in Paris pursuing my favorite studies. This bureau was 
closed in 1925 when I was transferred to the Bureau of Agricultural Extension.

Maublanc and Rangel, jointly and separately, gave to Brazilian phytopathology various and valuable contributions, which were published in national and foreign periodicals, among which mention should be made of Maublanc's list in the Bulletin of the International Institute of Agriculture of Rome (55), eiting the species existing at the time in the Herbarium of the Phytopathological Section of the National Museum. ${ }^{26 a}$ This material was collected and classified by the scientific personnel of the Museum.

Concerning the date of the occurrence of our principal plant diseases, in addition to those already mentioned, reference should be made to the following:

Cereal rust and more especially wheat rust, which has caused so much damage to the economic culture of this plant in Brazil, seems to have existed among us for more than a century and was mentioned by St. Hilaire (87) in connection with his trip through the interior (86). However, cereal rust was spoken of as if it were due to a single parasite, when in reality there are innumerable species and strains of rust, nearly all of which are strictly specialized. It was the great Swedish scientist Eriksson who determined correetly many of these species, principally on the basis of their biological peculiarities.

As to wheat rust, those who treated this subject in Brazil before 1908 (sic), ${ }^{27}$ attributed it to Puccinia graminis or black rust, when, as a matter of fact, as I explained in the Yearbook of the Polytechnical School in São Paulo of the same year (75), it should be identified with brown rust or Puccinia glumarum var. tritici. My opinion was clearly confirmed by Eriksson himself, ereator of the species, as you may see from the letter in which this eminent Swedish savant answered my inquiry.

However, in 1914 I believe, Engenio Rangel informed me that Puccinia graminis had been found in the South of Brazil and cited as evidence a specimen found in the herbarium of the Institute of Plant Biology, ${ }^{20}$ which had been collected there. I myself had occasion personally to observe the sudden appearance in 1923 of Puccinia graminis in my fields in Deodoro (Federal District), and in the seed plots of São Simø̃o in São Paulo, where it was introduced on seeds imported from Tunis.

However, Dr. Gassner informed me, and also published, ${ }^{28}$ that he had found Puccinia graminis when he went through Campinas in 1925 (sic). ${ }^{28}$ This leads me to believe that the parasite does not find in the central states of Brazil the biological conditions necessary to its repro- 
duction by teleutospores, but that it only develops sporadically by means of seed which are either contaminated or simply bearers of the living uredospores of the parasite.

The common scab of Citrus, sometimes called, it would seem incorrectly, "verrucosis" and in some states in the north of the country, "bostéla citrica," is indieated as being caused by Sphaceloma citri (Butl.) Puttem. nov. comb. (Sphaceloma fawcettii Jenk.) ${ }^{29}$; it did not exist in Brazil until 1913, at least not in the central states, and must have been introduced between that date and 1920. Certainly I could not have failed to notice a disease so characteristic that it attracted my special attention when I saw it for the first time in the sour orange nursery at the Piracicaba School. This was, as I recall it, toward the end of 1920, after my return from Europe, where I had remained during the World War. Soon after, that is in 1922, I found this same disease in the Federal District and I believe that at that time it was already widely distributed over the country. ${ }^{30}$ The specimens from the herbarium of the Institute of Plant Biology ${ }^{20}$ date from 1918. ${ }^{31}$

The potato disease caused by Phytophthora devastatrix (Lib.) Puttem. ${ }^{13}$, as I have just stated, has certainly existed for a long period in Brazil, probably since the middle of the last century. Personally I found it in Petropolis in 1892. However, in spite of all my efforts I never found the parasite on tomatoes, except in Europe. Nevertheless it was reported by Gregorio Bondar (Boletim do Lab. de Pathol. Vegetal No. 6, 1928) on specimens collected in Camassary (State of Bahia) by the state inspector of agriculture Dr. André Argollo Ferrāo. The Brazilian specimens of my collection were given to me by Dr. Müller, professor of phytopathology at the Agricultural School of Viçosa (Minas Geraes) where they were gathered on tomato plants in 1929.

This makes me think, as I published in 1922, that a race or strain of the parasite more especially adapted to the tomato was introduced a few years ago into Brazil, while another strain, a parasite exclusively of the potato, has existed here ever since the last century.

In 1912, on specimens collected in São Paulo by Mme. Puttemans, I noted the sudden appearance of the mildew of oak (Quercus spp.) (78) which a short time before had been found attacking oaks in certain parts of Europe, whenee it spread rapidly over nearly the whole continent.

In 1912 Professor Averna Saccá (4) published his findings of "Brusone" of rice in samples of rice collected in Iguapé. This is a very common and rather enigmatic disease, evidently caused in the majority of cases by Piricularia oryzae Cav., which the Japanese phytopathol- 
ogists consider, and in my opinion, with reason, synonymous with Piricularia grisea (Clke.) Sacc., common on other grasses. These species, however, would be better elassified in the genus Dactylaria.

Yet in 1912 and 1913, when I examined specimens given me by Averna Saccá, as well as abundant material collected by myself in the rice fields of São Paulo, I failed to find-just as I had failed before-a trace of the Piricularia. At the same time, I found this fungus in great abundance everywhere, on St. Augustine's grass (Stenotaphrum americanum Trin.).

The only specimens of this fungus collected on rice that I have in my herbarium, were sent to me by Professor Müller, who collected the material in Viçosa about five or six years ago. However, less than two years ago I found the same parasite on wheat in the Federal Capital, a hitherto unreported observation that seems to me to be new to science. I should add that among the numerous germination tests of rice seeds made under my direction at the Central Seed Testing and Supervising Laboratory of the Department of Agriculture the damage observed was caused by Helminthosporium an sativum $\mathrm{P}$. $\mathrm{K}$. and $\mathrm{B}$. and never, as was judged by some and as was plausible to believe, by Piricularia, so eașy to differentiate by the clavate form of the conidia and their position in a scorpioid cyme at the apex of the conidiophores.

These facts are indeed peculiar. In connection with "Brusone" I recall the great controversies which have arisen in the scientific world of Italy, as well as the curious fact that Butler did not mention the Piricularia of rice in India in his book "Fungi and Diseases of Plants."

In 1913, I sent to the laboratory of plant pathology of the Museum, some diseased leaves of Japanese plum (Eriobotrya japonica) from Petropolis. These when cultured in a moist chamber proved that the coffee disease caused by Stilbella flavida, identical with that known in Asia and Africa, and that which I collected later in Cubatão (São Paulo) and discussed in the Bulletin of the Mycological Society of France as long ago as 1904 (74), was simply the imperfect form of an almost microscopic Basidiomycete. This observation constituted a sensational fact, which Maublane and Rangel (56) presented in 1913 to the Academy of Sciences of Paris, giving the new fungus the name of Omphalia flavida.

Sugar cane mosaic was first found in Brazil in 1922, during an excursion in Campinas undertaken by an Italian scientist, Mario Calvino, on commission by the Cuban Government. In 1926, I showed (79) that the propagation of this virus disease was not due to the plant lice Aphis, as it is in other countries, but to a species of Thrips, to which Dr. Costa Lima (16) gave the name Thrips minulis var. Puttemansi. 
As to the filterable virus diseases which attack the potato, these were found and identified by me at Deodoro as early as 1921 (81). However, manifestations of potato degeneration had certainly existed here long before that and were attributed to little known physiological disturbances. These we know today are directly due to the presence of viruses in the diseased plants.

Mention should also be made of a disease of the same naturemosaic of the tobacco, which I was only able to identify positively in 1921 in the Federal District. I recognized then as unfounded a report published by me-with a certain amount of doubt, it is true,-in "Revista Agricola de São Paulo, identifying as mosaic a serious disease which today I can identify (unpublished communication) as caused by Bacterium pseudozoogloea described in 1914 by Honing in the tobacco crops of Deli (Sumatra) and transferred by Bergey, improperly, it would seem, to the genus Phytomonas.

I do not wish to prolong the enumeration of the first reports of certain plant diseases among us. Those who are especially interested in the subject may find in the respective bibliographies and especially in the phytopathological lists already published much valuable data, in regard to this part of the History of Phytopathology.

However, before elosing I would like again to call your attention to a most interesting subject, that is, that of plant diseases existing in other parts of the globe and not yet found in Brazil, though we have the plant hosts and similar mesological conditions. This is an extremely interesting subject in connection with the senitary protection of our plants-and the methods of adequate quarantine. Among these diseases I will mention coffee rust (Hemileia vastatrix $\mathrm{B}$. and $\mathrm{Br}$.); Citrus Canker: Bacterium citri (Hasse) Doidge, already reported by Averna Saccá in São Paulo, wrongly, as it happens, fortunately for our citrus growers; the canker and the powdery scab of the potatoes respectively; Synchytrium endobioticum (Schib.) Perc. and Spongospora subtervanea (Wallr.) Jonh.; the mildew of the lettuce; Bremia lactucae Regel; Cladosporium fulvum Cke. which I never found in Brazil, on tomatoes, its habitual host, but which I recently found on potato vines in. São Paulo (unpublished observation), thus presenting another and most intriguing biological and ecological problem. And the same may be said of all new diseases found on exotic plants.

In conclusion, should we wish to consider the ten most important periods or dates in the history of phytopathology in Brazil up to the present time, I would suggest in very general lines, the following:

1. Sporadic investigations made during the last century concerning the diseases of sugar cane, coffee, and grape vines. 
2. Mycological phase, that is, the systematic collection of Brazilian fungi.

3. Establishment of the first official phytopathological post in the Agronomical Institute of Campinas (1895) (sic). ${ }^{32}$

4. The work done by Fritz Noack in the above-mentioned Institute (1896-1898).

5. Establishment of the first course of phytopathology in the Agricultural Schools — São Paulo (1895 ?); Piracicaba (1901), etc.

6. Establishment of the Phytopathological Laboratory of the Ministry of Agriculture of the National Museum (1910).

7. Establishment of the Biological Institute of Agricultural Protection in the Ministry of Agriculture (1920), with the sections of phytopathology and of the selection of immune and resistant plants.

8. Establishment of the Bureau of Plant Quarantine (1922) and the contribution of Dr. Antonio M. Torres to the regional knowledge of our plant diseases and the inspection of our imported plants.

9. The appointment of Dr, A. A. Bitaneourt in 1923 (sic) ${ }^{33}$ as head of the Division of Phytopathology of the Biological Institute of São Paulo, a step which has given great impetus and more technical orientation to the phytopathological work in this progressive state.

10. The first phytopathological meeting of Brazil now being held, 1936, upon the initiative of Dr. H. V. S. Grillo.

\section{ADDENDA}

\section{Notes and himerature Citmo NoTes}

1 The fungi of Brazil were studied as early as 1821, when Martius (64) recorded ten species, chiefly mucors, illustrating them by means of color drawings. These species appear to have been inadvertently omitted from Berkeley and Cooke's (7) list of the fungi known from Brezil in 1876. As the title of their article indicates, their "primary object" was to "enumerate and describe the fungi collected by Trail in 1874 in the forests of Brazil," but they also included the "species previously described such as the eollections of Mr. Spruce" and "the species recorded by Messrs. Montagne, Leveille, Fries, and others." Interesting reference to the botanical explorations of Richard Spruce (71) is made in Cutright's recent book, "The great naturalists explore South America" (17).

On the basis of their enumeration of 437 species of fungi from Brazit, Berkeley and Cooke made the following comment:

"From comparison of this total number with the 886 enumerated for Cuba, and 1190 for Ceylon, it will be concluded at once that our knowledge of the Fungi of this vast tract of very favourable conntry is very limited and that but a small proportion of the whole mycologic flora is yet known. It may reasonably be assumed that the total number is not in reality less than in the smaller district comprised in the island of Ceylon." 
Noting that about three-fourths of the 437 species from Brazil belonged to the Hymenomycetes, Berkeley and Cooke (7) gave the systematic distribution of the total number as follows:

Hymenomycetes, 356; Gasteromycetes, 13;

Hyphomycetes, 5; Coniomycetes 55;

Ascomycetes, 55 ; Incomplete 1.

"About three hundred of the total number were confined to Brazil," these authors stated, "while 137 were found in other parts of the world." "They continued:

"The number common to Brazil and the Island of Cuba is 102, whilst 40 species are also found in the United States, 33 in Europe, 34 in India (including Ceylon), 18 in Australasian colonies and 4 are cosmopolitan."

These Inglish authors commented also upon the great absence of microscopic forms among the 437 species from Brazil, explaining this as "probably to be attributed rather to a deficiency on the part of the collectors than to their absence in the district." Mycological work as subsequently pursued in Brazil, has long since abundantly substantiated the conclusion of Berkeley and Cooke that "considerable additions to the mycologic flora" of Brazil might "yet" be "anticipated." At the same time, it has revealed the richness of this fungus flora.

The names of early mycological collectors of Brazilian fungi alluded to by Puttemans are of course perpetuated in mycological literature through generic and specific names coined from them. For convenience of reference in the following comments concerning the mycological collectors and descriptive botanists, most of whom were referred to by Puttemans, biographical references are given where available.

Fungi collected by Glaziou (14, 34) were identified by Berkeley (6).

The first descriptive list representing the early mycological collections of Ule in Southern Brazil was published (69) by Pazschke (37A), a.s well as a similar list (70) from the Itatiaia Mountains in the region of Rio de Janeiro. More extensive descriptive lists of Ule's collections, also published in Hedwigia are those by Hennings (49) from 1895 to 1908 , and by Rehm (3) from 1897 to 1904 . These are cited in one (33) of Frarms' biographical sketches $(32,33)$ of Ule. 'Examples of still other desoriptive lists of Ule's Brazilian fungi are those by Winter (68), and by the Sydows, published in 1887 (104) and 1916 (96) respectively.

Hennings (35), who also published similar descriptive lists of Moeller's Brazilian fungi, noted that while Ule's collections were mostly leaf parasites, the fungi collected by Moeller $(23,24,42)$ were generally fleshy or of compact form. Among Moeller's beautifully illustrated series of publications on Brazilian fungi, listed by Jahn (42), two well-known examples are here cited $(57,58)$.

A mycological publication by Usteri (99) deals with a fungus on Paspalum.

Torrend $(97,98)$ in his mycological work has, of course, given particular attention to myxomycetes including those of Brezil. Although a member of the "Primeira Reuniäo de Phytopathologistas do Brasil," unfortunately Rev. Torrend was not in attendance.

Theissen's extensive publications, many dealing with fungi from Southern Brazil, are listed by Luisier (63). Similarly, von Hoehnel's are assembled by his biogrepher, Weese (101).

2 An interesting ascomycete from this source (90, p. 590), now known as Dermatea parasitica (Wint.) v. Hoehn., was rediscovered at Itanhaen, São Paulo, in 1936 by H. P. Krug, A. S. Costa, and A. E. Jenkins (47).

In 1896, in listing the eryptogams in the herbarium of the Commission, 
Edwall (22) stated that the greater part of them had been determined by Puiggari. Among the fungi, numbering about 100 specimens, a few were from Apiahy, as were some of the ferns and many of the lichens.

4 The private herbarium of Arsène Puttemans has been purchased by the National College of Agrieulture-Escola Nacional de Agronomia - of Rio de Janeiro. Aocording to Dr. Grillo, the present curator, this herbarium, constituting an excellent repository of exsiccati of Brazilian fungi, will afford opportunity for research by specialists in various fields of mycology for meny years.

${ }^{5}$ It was Erwin F. Smith (89) who interpreted Dreenert's work as dealing with a bacterial disease, viz., Cobb's disease of sugar cane. Such interpretation was made only in 1914, in connection with Smith's report on this disease. He cites Draenert's two articles on the subject both published in $1869(20,21)$, only the second of which was referred to by Puttemans. For convenience of reference excerpts from Smith's discussion of Draenert's articles are here quoted, and the illustrations which Smith cites are also reproduced (Plate II).

"Inasmuch as the disease had been ascribed to insects by one of the Commissions, Dränert first examined for borers, Coecus sp., eto., but could not in any way connect them causally with the disease. The disease occurred when they were absent and vice versa. On the other hand, as a result of microseopic examinations, he found various minute vegetable organisms in the languishing cane, and to them he ascribed the disease. Accepting Hallier's peculiar view of polymorphism, he believed all these to be various stages of one organism, and experimenting in the same crude way as Hallier, believed he had demonstrated that one grew out of the other. He spealrs mostly of an alga as the cause of the disease, but this is only becauge he believed that to be the terminal stage in the development of the microscopic organisms (bacteria) seen by him in the yellow gum. These latter were considered to be the spores of the algae, or the reduced forms of the spores. He figures a micrococcus, $a$ oryptococcus (yeast), and one or more fungous or algal (?) bodies as stages of this paresite. Owing to the imperfect technic of the time he was unable to obtain from his cultures results of any value and some of his reasoning is of the post hoc sort. Nevertheless, I believe we may safely accept such of his statements as are based on field observations, and also some of the simpler conclusions be drew from his mioroscopic examinations. He figures nothing resembling Bacterium vascularum, but his micrococous is about the right size and it is very easy to understand how he should have mistaken short rods for a coccus, especially with the crude microscope he is likely to have used. There is no doubt whatever in my own mind that the Brazilian cane-diseaso studied by him was really that subsequently deseribed from Australia by Cobb. He sary the top-rot, the bacterial slime, and the red stain in the bundles. ..."

"In a, second brief communication (21) (an excerpt from a letter to Hallier), after speaking of the discovery of a cryptococcus (yeast) in the juice freshly squeezed from diseased cane, Dränert goes on to say: 'In the same juice there are, however, in much greater numbers, that little cell (fig. 58, a) probably the same that you name Micrococcus.' A little further on we have the following confirmatory sentence: 'From such cane the yellow material was collected which, dissolved in water, appears as a mierococeus.' He then goes on to state as facts what in the light of our present more exact knowledge we know to be only inferences drawn from inexaot observation, to-wit, how these micrococei in 24 hours grow out into those algal threads he has already described and figured."2

- Burrill's several publieations on blight were listed by Stewart (91). 
7 Among the seyeral biographical sketches of Gooldi axailable (2, 66, 92, 100), one mentions his work with plant diseases, and is here quoted:

"Professor Dr. August Göldi, born in 1859 in Toggenburg, received his first education at the Gymnasium (college) in Sohaffhausen, where he was greatly enoouraged in his predilection for natural history by the investigator and explorex of prehistorical strata Professor Nüesch. He subsequently studied in Naples and Jena, obtained his Ph.D. degree under Haeckel and then followed his natural inclination for natural history. He went to Rio do Janeiro and accepted a position as professor and Director of the Museum. 'The emperor Don Pedro, whose attention was called to Göldi and his activity, appointed him to the position as an expert of plant disease. In this eapacity he had an excellent opportunity of travelling all over the country and of making observations and investigations. However, the revolution of 1889 destroyed all his beautiful plants. In 1894 he went to Para, taking charge of the Museum, which under his management became an outstanding institution with regard to the organization and richness of collections, so that it was named in his honor Museu Göldi. On account of his health he returned in 1905 to Bern and accepted here \& position as professor of animal geography and biology at the university. His publications are very numerous, over 200 in number. Outstanding among these is his monograph on Tipulidae of Para; the sanitary, pathologieal importance of insects, especially as carriers and transmitters of diseases. In the midst of his activity he died in 1917.22

The source of this biographical sketch has not been ascertained. It appears on a typewritten sheet pasted on the reverse of Goeldi's portrait as mounted in the photograph collection of the Bureau of Entomology and Plant Quarantine, U. S. Department of Agriculture.

"The expression "molestia dos olhos pardos" appears to have originated with Benecke, who used it several years prior to 1902. See "Café Molestia já conhecidas" in the report by Dafert $(18$, p. 320$)$.

${ }^{9}$ Goeldi $(30$, p. 38$)$ stated that his alassification of the fungus as Ramularia (Cercospora) was approved by the eminent botanist Professor Dr. Hermann Karsten $(1,71)$ of Berlin, well known for his travels in the Andes.

10 This dato evidently should be 1895 .

II In his first report (1910) as Director of the Laboratory of Phytopathology of the National Museum, organized three months boforo, Puttemans (80) reported grape anthracnose as the most destructive disease of European grapes in Brazil. This report remained in manuscript until 1934, as noted by Puttemans on page 91. of the translation.

12 Although it seems logical to oite Elsinoë viticola Racib. as the perfect stage of Sphaceloma ampelinum D By., it is perhaps preferable at present to use the name Elsinoë ampelina (D By.) Shear.

${ }_{18}$ This organism is generally lmown as Phytophthora infestans (Mont.) de Bary. Phylophthoa devastatrix is employed by Puttemans (82) for reasons of priority.

is The volume just cited also contains Noack's account of diseases and pests of wheat (63), which is accompanied by a colored plate of his own drawings.

Another publication by Noack, also not directly mentioned by Puttemans, is his account of oitrus diseases in Brazil, which was published (65) in Germany soon after his return. This contains Noack's report and discussion of the Grind, now interpreted $(11,46)$ as probably sweet orange fruit sab. In recent correspondence with Professor H. Sydow (letter dated January 9, 1939) it was learned 
that among the specimens collected by Noack in Brazil (95), there was a specimen of the Grind. But, as Sydow explained in his letter, this specimen was discarded and not included in the list just eited, because it showed only an obseure unidentified fungus. These facts, including the indeterminate condition of the fungus associated with the Grind, as studied by Noack (65), actually strengthen the belief that Noack was dealing with the pathogene of sweet orange fruit seab. This was identified in 1933 as the myriangiaceous species Sphaceloma favcetti var. viscosa Jenkins (44) and somerwhat Iater was studied further by Bitancourt and Jenkins $(8,10,12)$, whọ classified it in its perfeet stage as Elsinoë australis.

In 1939, at the suggestion of Professor H. S. Faweett, specimens of citrus fungi colleoted in Sāo Paulo by Noack were borrowed from the herbarium of P. Sydow, through the kindness of Professor G. Samuelsson, Botany Department, Natuxhistoriska Riksmuseet, Stoekholm, Sweden, in order that they might be examined for possible lesions of street orange fruit scab. None were found, so that Noack's description of the Grind stands as the only record of his discovery of this disease in Brazil.

Sweet orange fruit scab, overlooked for many years, became of importance particularly to the Brazilian citrus industry about ten years ago (11). The survey of eitrus diseases in South America in $1937(25,26,27)$ yielded important information concerning the geographic distribution of this disease, as well as the kinds of citrus attacked.

The Sydows (95) stated that among the specimens received from Noack, the Basidiomyeetes were referred to Patouillard (67) the single ascomycete to Rehm (83), and the myxomycetes to Jahn. Several of the new species were named in honor of Nonok. A speoies of Septobasidium studied by Patouillard was classified in the new sub-genus Noackia.

${ }^{15}$ As shown elsewhere (46) this monograph consists of two articles, one by Campos Novaes (15), and the other by Noack (64).

1e "This date evidently should be 1901."

${ }^{17}$ Dr. Gustavo Edwall was author with Loefgren (13) of Flora Paulista (60, 52).

${ }^{18} \mathrm{~A}$ genus and species that Hennings (36) found particularly interesting is Myriangina mirabile (Henn.) Hoehn. elso diseussed by von Hoehnel (38). This species is based on a fungus pathogenic on Nectandra (Lauraceae) which Puttemans discovered in the forests of the Cantareira Mountains. This fungus was rediscovered in the type locality in April 1936 by S. C. Aruda, i.e., it was found at Cantareira on leaves of trees growing near the laboratory of the Phytopathological Section of Instituto Biologico. Recognizing the species as almost certainly Myriangina mirabile, Jenkins, at the time stationed at the Phytopathological Laboratory (10, footnote 1) took advantage of the opportunity to send a specimen to Dr. Puttemans. He verified the identification and sent a gift of four specimens of the Myriangina collected on Nectandra at Cantareira and vicinity between 1900 and 1912. This fungus, which was illustrated by Jenkins in 1931 (43), has been found (94) on the Nectandra substrate in Costa Rica.

10 Besides the genus Puttemansia, Hennings also named that of Puttemansiella (37, IV, p. 10) for Puttemans and a number of species have been desoribed in his honor. Puttemansia lanosa and Pullemansiella desmodii, the type species of the two genera just mentioned, were both originally collected in the Cantareira Mountains, the first fungus on Neciandra sp. and the second on Desmodium leiocarpum. Among the specimens received by the writer from Dr. Puttemans were two of 
P. lanosa, part of the type colleetion by A. Hamar and a gathering by Dr. Puttemans in 1905. P. lanosa is now recorded from Costa Rica (94) whence another species of the genus has been described (93).

Probably the most recent species which bears Puttemans' name is Phoma puttemansii Benatar (5) which causes a fruit rot of sweet orange (Citrus sinensis Osb.). The first of a series of illustrations shown by Benatar is a photograph of a specimen labelled "Phoma sp.," that was collected by Puttemans in a market in SẼo Paulo on December third, 1912. The characteristic typewritten label often used by Puttemans is also represented.

${ }^{20}$ The Institute of Plant Biology is now part of the Forest Service (Servico Elorestal).

II In 1934 Dr. A. S, Mïller (59), then Mycologist and Plant Pathologist at the State College of Agriculture, Viçosa, Minas Gerais, Brazil, named the late Dr. Puttemans as one of "three living active mycologists who had been collectors over a period of some thirty years in eastern central Brazil" and who possessed "excellent private herbaria." The other two mycologists mentioned were Drs. Eugenio Rangel and Rosario Averna Sacck.

22 The twenty-ninth anniversary of the founding of this college-Escola Superior de Agricola "Luiz de Queiroz" de Piracicaba-was recognized by a Commemorative Number of "O Solo" ( $\mathrm{Vol} .22, \mathrm{Nos} .5$ and 6 ), which contains an article by E. E. Honey $(40)$.

${ }^{23}$ In contemporary articles more recent phases of phytopathology in Brazil have been discussed by Grillo (31) and by Muller (60). Dr. Grillo refers to the Iaboratories of plant pathology at the schools of agriculture at Piracicaba and at Viçosa organized by the American professors Edwin $\mathrm{E}$. Honey and Albert S. Müller. Reference is made to the progressive Phytopathological Section of the Biological Institute of São Paulo, organized by Dr. A. A. Bitencourt. As an indication of the scientific cooperation sponsored by the Institute, Dr. Grillo mentioned the presence there of two foreign microbiologists, Dr. Karl Silberschmidt, and Dr. Anna F. Jenkins. The year after Dr. Grillo's article was written, Professor H. S. Feweett also spent over half a year in Brazil worling in cooperation with Dr. Bitancourt. It was at this time that they made the survey of citrus diserses in South America previously cited (25, 26, 27). When Dr. Grillo's article just cited was written, he was the professor in charge of the excellently equipped phytopathological laboratory of the National College of Agriculture of Brazil, of which he is now President.

21 The date 1908 is probably a typographical error for 1904, the date of the publication. In the first article cited Rick gives a resume of the accomplishment until then in the field of mycology in the State of Rio Grande do Sul.

${ }_{25}$ The artiole to which Dr. Puttemans referred and which he cited later (80) is by Weimer (102).

20 Puttemans (80) explained that about twenty per cent of the pathological material examined represented new species of fungi or those not well known. In supplementary notes ("Notas redigigas posteriormente pelo auctor"), $\mathrm{p}$. 24-25, publishod with his report, Puttemans included a technical description of the new species Puccinia justiciae on Justicia pectoralis which he listed as new in the unpublished report of 1910. In doing so, he explained that he believed he had previously published this description in one of the volumes of the "Archives do Museu Nacional de Rio de Janeiro," but that "it was not at the moment convenient to verify this fact, although the description had not been published in. Saccardo's Sylloge Fungorum." 
Puttemans's illustration of this species as contained in the original report is here reproduced (Plate V) and the description as published in his supplementary notes in 1934 is quoted below:

"Puccinia justiciae Puttem.

Maculis nullis vel matrice tumefactae pallescente; soris hypophyllis, xaro epiphyllis, minutis, sparsis vel suborbiculariter dispostis e confluentibus, primo tectis demum liberis, sordide cinnamomeis; uredosporis globosis ca. $25-32=$ 20-24 aculeolatis, luteo-fuseis; teleutosporis oblongo-ovatis vel subpolygonis $30-10 \times 25-30$, glabris vel dilute e irregulariter verruculosis, fuscis, episporio ea. 5 crasso; pedicello persistente, hyalino, recto vel subflexuoso usque ad 60 longo, basi aspero, subinde oblique ineerto; monosporis numerosis, globosis 28-38.

Hab. in foliis Justiciae pectoralis pr. Rio de Janeiro, Brasilae."

Of the eight illustrations in this article, those of "Alternaria brassicae and Cercospora chrysanthemi Puttemans were published in the Bulletin de la Société Royale de Botanique de Belgique (77).

28a A subsequent list as of 1936 has been published by Grillo (31a), who gave as the first lists of plant diseases published in Brazil those of Puttemans of 1901 (Loefgren 61) and 1906 (76) already cited.

${ }^{27}$ In the originel text 1908 is apparently a typographical error for 1905.

${ }^{28}$ Puttemans gave the date 1925, but the date as given in Gassner's article is 1927 (28, p. 193).

20 Dx. Puttemans article was presented in January 1936. In that same month a paper by Jenkins (45) presented evidence showing that Sporotrichum citri Butler (19) is a species of Sphaceloma. There was also in press at the same time the technical description of the perfect atage of Sphaceloma fawcetti Jenkins as Flsinoë ferzcetti Bitancourt and Jenkins (9).

${ }^{30}$ One evening during the Reuniăo in January 1936 Drs. A. S. Müller, H. V. S. Grillo, A. A. Bitancourt, and A. E. Jenkins were guests in the home of Dr. and Mrs. Puttemans, and had the opportunity of seeing the specimens of citrus scab, and other eitrus diseases collected in Brazil by Dr. Puttemans; the earliest epecimens of citrus scab bore the date 1922 (61).

- ${ }^{31}$ The speoimens of 1918 to which Dr. Puttemans refers was collected at Deodora on April 3, 1918 (46).

${ }^{32}$ It would seem that this date should be 1888 . See page 24 of text and page 85 of this copy of the translation.

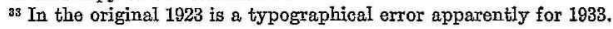

ITTHRATURE CITED

1. Anonymous. [Dr. Hermann Karsten]. In Biographische Mitteilungen. Leopoldina 44: 94-95. 1908.

2. Anonymous. Emil A. Goeldi. Physis 4: 381. 1918.

3. Arnold, K. F. Heinriob Rehm. Ber. Bayer. Bot. Ges. 16: 10-13. 1917. Portrait and bibliography.

4. Averna Saccá, R. O "Brusone" do arroz. Bol. Agr. [Săo Paulo] 13: 291-302 1912.

5. Benatar, R. Sobre uma nova mancha em epicarpo de Citrus sinensis Osbeok causada pelo Phoma puttemansii n. sp. Rodriguésia 2: 306-313. 1936. 
6. Berkeley, M. J. Fungi Brasilienses in provincia Rio de Janeiro a clar. Dr. A. Glaziou lecti. In Warming, E. Symbolae ad floram Brasiliae centralis cognoscendam. Vidensk. Medd. Naturh. For. Kjobenhavn 31-32: 31-34. 1879-80.

7. Berkeley, M. J. and Cooke, M. C. The fungi of Brazil, inchuding those collected by J. W. H. Trail, Esq., M.A., in 1874. Jour. Linn. Soc. Bot. 15: $363-398.1877$.

8. Bìtancourt, A. A. and Jenkins, A. E. Variações de Elsinoë australis Bitancourt e Jenkins. Abstract. Rodriguésia. 2: Numero Especial (Annaes d8 Primeira reunião de Phytopathologistas do Brasil): 315-317. 1936 (1937).

9. Bitancourt, A. A. anđ Jenkins, A. E. Ellsinoe fawcetti, the perfect stage of the citrus soab fungus. Phytopathology 26: 393-396. 1936.

10. Bitancourt, A. A. and Jentrins, A. E. Perfect stage of the sweet orange fruit seab fungus. Mycologia 28: 489-492. 1936.

11. Bitancourt, A. A. and Jenkins, A. E. Sweet orange fruit scab caured by Elsinoë custralis. Jour. Agr. Research 54: 1-18. 1937.

12. Bitancourt, A. A. and Jenkins, A. E. Ciolo evolutivo de Elsinoë australis Bitancourt e Jenkins, agente da verrugose da laranja doce. Aroh. Inst. Biol., S̃̃o Paño 10: 129-146. 1939.

13. "Bn., E." Alberto Löfgren. Physis 4: 380-381. 1918.

14. Bureau, E. Notice historique sur F. M. Glaziou. Bul. Soc. Bot. de France 55: 119-125. 1908. (Portrait).

15. Campos Novaes, J. Cryptogamos microseopicos das videiras. Bol. Inst. Agron. Est. São Paulo (Campinas). 10: 51-90. 1899.

16. Costa Lima, A. de. A proposito de uma communicação do Dr. Puttemans sobre a mosaico de canna de assucar. Chacaras e Quintaes 34: 30-32. 1926.

17. Cutright, P. R. The great naturalists explore South America. $340 \mathrm{p}$. New York. 1940.

18. Dafert, F. W. Molestias de plantas observados no estado em 1894 e 1895. In Relatorio annual do Inst. Agron. Est. São Paulo (Campinas) 18941895. 7 and 8: 317-328. 1896 .

19. Doidge, E. M. and Butler, E. J. The cause of citrus scab. Trans. Brit. Mycol. Soc. 10: 119-121. 1924.

20. Draenert, F. M. Bericht über die Krankheit des Zuckerrohres. Zeitschrift für Parasitenkunde 1: 13-17. 1869.

21. Draenert, F. M. Weitere Notizen über die Krankheit des Zuckerrohrs. Zeitsohrift für Parasitenkunde 1: 212. 1869.

22. Edwall, G. Cryptogamae. Indiee das plantas do herbario da commissüo. In Bol. Comm. Geog. e Geol. de São Paulo. 11: 185-215. 1896.

23. Falck, R. Nachruf für Alfred Möller. Mykol. Unters, u. Ber, 2: 1-10. 1923.

24. Faick, R. Alfred Möller. His Hausschwammoforschungen 9: 1-11. 1927 (Portrait).

25. Fawcett, H. S. and Bitancourt, A. A. Relatorio sobre as doenças dos Citrus nos Estados de Pernambuco, Bahia, Săo Paulo e Rio Grande do Sul. Rodriguésia (Rio de Janeiro) 3: 213-236. 1937.

26. Fawcett, H. S, and Bitancourt, A. A. Observaciones sobre las endermedades de los eitrus en el Uruguay. Revista Asoc. Ingea. Agron Montevideo $12(3): 3-8 . \quad 1940$. 


\section{THE JOURAYAL OF AGRICULTURE OF THE UNIVRRSITX OF P. R.}

27. Fawcett, H. S., Grillo, H. V. S., Bitancourt, A. A. and Mitller, A. S. Relatorio sobre as doengas dos Citrus no Distrito Federal, Estado do Rio de Janeiro e Minas Gerais. Rodriguésia (Rio de Janeiro) 2: 329-344. 1936.

28. Gassner, G. Neue Feststellungen über Auftreten und Verbreitung der Getreiderostarten in Südamerica. Phytopath. Zeitsohr. 4: 189-203. 1931.

-29. Goeldi, E, A. Relatorio provisorio sobre a commissăo relativa ás molestias da parreira na provincia de Săo Paulo, principalmente quanto a questão phylloxerica. Rio de Janeiro. Imp. Inst. Flum. Rev. Agr., 20: 59-75. 1889.

30. Goeldi, E. A. Relatorio sobre a molestia do cafeeiro na provincia do Rio de Janeiro 1887. Arch. Mus. Nac. do Rio de Janeiro, 8: 8-123. 1892.

31. Grillo, H. V.S. A evolução da Phytopathologia. Rodrigú́sia 1: (3) 2-11. 1935.

31a. Grillo, H. V. S. Iista preliminar dos fungos assignalados em plantas do Brasil. Rodriguésia 2 (Num. esp.): 39-96. 1936 (1937).

31b. Grillo, H. V. S. As necessidades da phytopathologia no Brasil. Rodriguésia 2 (Num. esp.) : 109-113. 1936 (1939).

32. Harms, H. Ernest Ule. Ber. Deut. Bot. Ges, 33: (52)-(59). 1915.

33. Elarms, E. Nachruf auf Ernst Ule. Verhandl. Bot. Vereins der Provinz Brandenburg 57: 150-184. 1916. Portrait and bibliography.

34. Hemsley, W. B. Auguste Franģois Marie Glaziou. Bul. Misc. Inf. Kew. 1907. 66-68.

35. Hennings, P. Fungi blumenavienses a cl. Alfr. Möller leoti. Hedwigia 34: 335-338. 1895; 41: 1-33, 1902.

36. Hennings, P. Myriangium mirabile P. Henn. n. sp., sowie Bemerkungen über verschiedene andere Arten der Myriangiaceen. Hedwigia 41: (54) $-(56) .1902$.

37. Hennings, P. Fungi S. Paulenses a cl. Puttemans collecti I.-IV. Hedwigia 41: 104-118; 295-311. 1902; 43: 197-209. 1904; 48: 1-20. 1909.

37A. Hermann, E. Dr. O. Pazschke. Zeitschr. Pilzk. 2: 130-131. Jena. 1923. 38. Hoehnel, F, von Elsinoëen. Fragmente zur Mykologie (VI. Mitteilung, Nr. 244). Sitzber. Akad. Wiss. Wien, Math.-Naturw. Kl, 118: 372-373. 1909.

39. Hoehnel, F. von Puttemansia lanosa P. Henn, Fragmente zur Mykologie (XII. Mitteilung, Nr. 602). Sitzber. Akgd. Wiss. Wien, Math.-Naturw. Kl. 119: 899-901. 1910 .

40. Honey, E. E. Srudação aus alunos de Escola Agricola. O Solo 22: 183188. 1930.

41. Howard, L. O. Some pioneers in mosquito senitation and other mosquito work. II Pop. Sci. Monthly $87:$ 169-180. 1915.

42. Jahn, E. Alfred Möller. Ber. Deut. Bot. Ges. 41: (75)-(83)., 1924. Bibliography.

43. Jenkins, A. E. Scab of Canavalia caused by Elsinoë canavaliae. Jour. Agr. Research 42: 1-12. 1931.

44. Jenkins, A.E. A Sphaceloma iattacking Navel orange from Brazil. Phytopathology 23: 538-545. 1983.

45. Jenkins, A. E. Present generic status of the citrus-scab organism. Phytopathology 26: 68-70. 1986.

46. Jenkins, A. E. and Bitancourt, A. A. Illustraçōes das doenças causadas por 
Elsinoë e Sphaceloma conhecidas na America do Sul até Janeiro de 1936. Arq. Inst. Biol. Săo Paulo. 10: 31-60. 1939.

47. Jenkins, A. E., Krug, H. P., and Cash, E. K. New or little known ascomycetes collected in São Paulo in 1936. Mycologia. (Unpubliøhed.)

48. Jobert, C. Sur une maladie du caféier observée au Brésil. Acad. des Sci. Compt. Rend. [Рaris] 87 : 941-943. 1878.

49. Lindau, G. Paul Hennings. Hedwigia 48: 1-5. 1909. Portrait.

50. Loefgren, A. Contribuiçōes para a botanica Paulista. Memoria das excursర̃es botanicas de 1887, 1888, e 1889. Comm. Geog. e Geol. de São Paulo. Bol. 5,61 p. 1890.

51. Loefgren, A. Relatorio da Seç̧ão da Botanica. Comm. Geog. e Geol. de São Paulo 1901, 46-49. 1902.

52. Loefgren, A. and Edwall, G. Flora Peulista I-1V. Săo Paulo. 1897-1905. Bol. 12-15. (Parts I and III by Loefgren and II and IV by Edwall).

53. Luisier, A. O. P. Fernando Theissen S. J. Broteria Bot. Ser. 18: 73-78. 、 1920 .

54. Martius, K. F. P. Decas plantarum mycetoidearum quas in itinere brasiliensi observavit. Nova Acta Acad. Caes. Nat. Cur. 10: 502-512. 1821.

55. Maublanc, A. Rapport sur les maladies observées au laboratoire de Phytopathologie du Musée nacional de Rio de Janeiro. Inst. Inter. Agri. Extrait. Bul. Mens. Rens. Agr. Mal, Plantes. Année, 4, No. 6, 6 p. 1913.

56. Maublanc, A. et Rangel, E. Le Sitlbum flavidum Cooke, parasite du cafeier et sa place dans la classification. Compt. Rend. des Śances de l'Acad. des Sci. [Paris] 167: 858-860. 1913.

57. Moeller, A. Die Pilzgärten einiger sud-amerikanischer Ameisen. In A. F. W. Sehimper's Bot. Mitt. a. d. Tropen 6, 127 p. Jens. 1893.

58. Moeller, A. Phycomyceten und ascomyceten untersuchungen aus Brasilien. In A. F. W. Schimper's Bot. Mitt. a. d. Tropen 9:319 p. Jena. 1901.

59. Müller, A. S. Mycology in Brazil today. Mycologia 26: 192. 1934.

60. Míller, A. S. Observaçōes sobre o ensino da Phytopathologia no Brasil. Rodriguesia 2 (Num. Esp.): 145-147. 1936 (1937).

61. Mutller, A. S. and Bitancourt, A. A. As doenças dos Citrus no herbario de A. Puttemans. O Biologico (S巨̃o Paulo). 2: 65-66. 1936.

62. Noack, F. Cogumelos parasitas das plantas de pomar, horta o jardim. Bol. Inst. Agron. do Estado de Sāo Peulo (Campinas). 9:75-88. 1898.

63. Noack, F. Molestias do Trigo. Bol. Inst. Agron. do Estado de São Paulo (Campinas), 9: 161-168. '1898.

64. Noack, F. Molestias das videiras. Bol. Ingt. Agron. do Estado de Säo Paulo (Campinas) 10: 91-112. 1899.

65. Noack, F. Pilzkrankheiten der Orangebaume in Brazilien. Ztschr. Pflanzenkrank, 10: [321]-335. 1800.

66. Palmer, T. S. [Dr. Emil August Goeldi]. The Auk 34: 510. 1917.

67. Patouillard, N. Basidiomycétes nouveaux du Brésil recueillis par F. Noack. Ann. Myc. 5: 364-366. 1907.

68. Pazschke, O. Dr. Georg Winter Ein Nachruf. Hedwigia 26: 185-191. 1887. Portrait and bibliography.

69. Pazschke, O. Erstes Verzeichniqs der von E. Ule in den Jahren 1883-87 in Brasilien gesammelten Pilze. Hedwigia 31: 93-114. 1892.

70. Pazschke, $O$. II. Verzeichniss brasilianiseher von $\mathrm{E}$. Ule gesammelter

. Pilze. Hedwigia 95: 50-55. 1896. 
71. Pittier, H. Investigación de la flora de Venezuela y estado actual de nuestros conocimientos acerca de ella. His Las plantas usuales de Venezuelz. Pp. 1-11. 1926. Contains portraits of Richard Spruce and Hermann Karsten.

72. Prillieur, E. Maladies des plantes agricoles et des-arbres fruitiers et forestiers causées par des parasites végétaux. Paris. 1: 1-37. 1895.

73. Pulggari, J. I. Noticia sobre algumas criptógamas nuevas halladas en Apiahy, Provincia de Sāo Pablo, en el Brasil. Ann. Soc. Cient. Argentine. 11: 201-216. 1881.

74. Puttemans, A. Sur la maladie du caféier produite par le Stilbella flavida. Bul. Soc. Mycol. de France, 20: 157-164. 1904.

75. Puttemans, A. Ferrugem das cereas om S. Paulo. Ann. Escola.Polytech. de São Paulo para 1905. 5: 82-102. 1905.

76. Puttemans, A. Relaçāo dos fungos parasitarios observados nos hortos de ensajos da Escola Polytechnica de São Paulo durante o anno de 19051906. Ann. Escola Polytech. de Säo Paulo para 1906. 6: 37-46. 1806.

77. Puttemans, A. Nourelles maladies de plantas cultivées. Bull Soc. Bot. Belgique 48: 235-247. 1911.

78. Puttemans, A. Sur l'Oidium du Chêne au Brésil. Bul. Soc. Vég. Path. Fr. $7: 37-40.1920$.

79. Puttemans, A. O "mosaico" da Canna de Assucar. Bol. Min. Agr. Indús. e Com. Rio de Janeiro. 1926, 2: 350-355.

80. Puttemans, A. Ligeira contribuição a Phytopathologia Brasileira. O Campo 5: 20-25. 1934 .

81. Puttemans, A. Informaçũes sobre "Doenças de Degenerescencis da Batateira" no Brasil. Rev. Agri. (Piracicaba) Sే̄o Paulo 9: 103-11. 1934.

82. Puttemans, A. Reivindicaşo visando a denominaçẽo scientifioa da doença da batateira. Rodriguésia 2 (Num. Esp.): 340-350. 1936 (1937).

83. Rehm, H. Peroneutypella Noackii Rehm. Ascomycetes austro-americani. Ascorayeetes novi. Ann. Myc. 5: 521-533. 1905.

84. Rick, J. Fungos do Rio Grande do Sul (Brasil), Broteria 3: 276-293. 1904.

85. Rick, J. Fungi austro-americani. Ann. Mycol. 2: 406-410. 1904; 3: 15-18 (1905); 4: 309-312. 1906; 5: 28-31, 335-338. 1907; 6: 105-108. 1908; 9: 175-184. 1911.

86. St. Hilaire, A. F. C. P. de. Voyages dans l'interieur du Brésil. 8 v. in 4. (Paris, 1830-1851). See Vol. 1, part 1, pages 391 and 448; part 2, p. 27 and Vol. 4, part 2, p. 24.

87. Sampaio, A. J. de. Auguste de Saint Hilaire. Bol. Mus. Noc. 4; 1-33. 1928.

88. Smith, E. F. The earliest workers. His Bacteria in relation to plant diseases. 2: 7-9. 1911.

89. Smith, E. F. Cobb's sugar cane disease. His Bacteria in relation to plant diseases, 3: 3-71. 1914.

90. Spegazzini, C. Fungi puiggariani. Pugillus I. Bol. Acad. Nac. Cienc. Cordoba 11: 381-622. 1899.

91. Stewart, Y. B. The fire blight disease in nursery stock. Cornell Univ. Agr. Exp. Sta. Bul. 329: 315-371. 1909.

92. Studer, T. Professor Dr. Emil August Goeldi. Verhandi. Sehweiz Naturf. Gesellschaft, Zürich. 24 p. 1917. Reprint. Bibliography.

93. Sydow, H. Fungi in itinere costaricensi collecti. Ann. Myc. 23: 361-363. 1925. 
94. Sydow, H. and Petrak, F. Fungi costaricenses a cl. Professor Alberto M. Brenes collecti. Ann. Myc. 27: 45-46. 1929.

95. Sydow, H. and Sydow, P. Yerzeichnis der von Herrn. F. Noack in Brasilien gesammelten Pilze. Ann. Mycol. 5: 348-363. 1907.

96. Sydow, H. and Sydow, P. Fungi amazonici a cl. E. Ule lecti. Ann. Myc. 14: 65-97. 1916.

97. Torrend, C. Les myxomycètes. Etude des espèces connues jusqu'ici. Broteria 6: 5-64. 1907; 7: 5-177. 1908.

98. Torrend, C. Les myxomycètes du Brésil, eonnus jusqu'ici. Broteria Ser. Bot. 13: 72-78. 1915.

99. Usteri, A. Cerebella paspali Ces̊ti un parasite sur les grains de Paspalum notaium Flügge et $P$. monostachyum H.B.K. Ann. Esc. Polytechn. Săo Paulo para 1906. 6: 17-27.

100. ${ }_{-k}^{6}$ Vaz, Z. A vida e os trabalhos de Emilio Goeldi. Bol. Biol. (Süo Paulo) 2: 3-17. 1934.

101. Weese, J. F. ซ. Hoehnel. Ber. Deut. Bot. Ges. 38: (103)-(126). 1921. Bibliography.

102. Weimer, J. L. Alternaria leaf spot and brownrot of cauliflower. Jour. Agr. Research 29: 421-441. 1924.

103. WhetzeI, H. F. An outline of the history of Phytopathology. Philadelphia and Erondon. 1918. $130 \mathrm{p}$.

101. Winter, G. Fungi novi brasilienses. Grevillea 15: 86-92. 1887. 


\section{PLATE I}
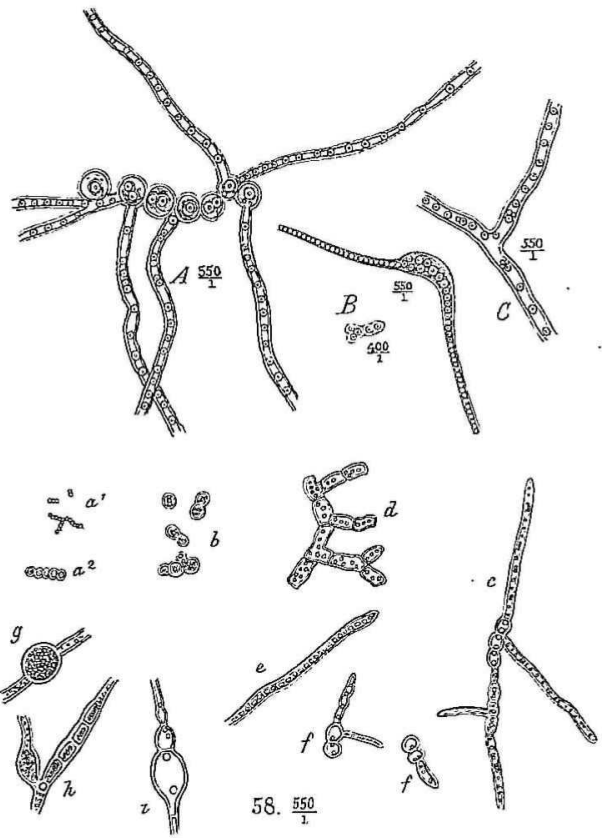

Mlustrations accompanying Draenert's articles, " $A-C$ " accompanying the first (20) and "Fig. 58 " the second (21). The legends are quoted in the original German.

"A-C. Parasit des Zuckerrohrs.

"A. Grosse Zellon, mit Inhaltszollen, welche zum Theil seitlicho Füden getrieben haben.

"B. C. Fäden mit kleinen Inhaltszellen."

"Fig. 58. Der Parasit der Zuckerkrankheit;

(a) Cocci, in Theilung, Kettenbildung und Sehreellung begriffen,

(b) dem Cryptococeus ähnliche Zellen,

(c) Keimfäden, Keimungsprodukt der vorigen

(d) gegliedertes Bruchstück eines Keimlinge,

(e) algenartiger Faden eines solehen,

()$\left.^{\prime}\right)$ kleine Keimlinge,

(g) Anschwellung des Fadens mit einem Sporangium,

(h) desgleichen mit anders gestalteten Frïchten." 
PLATE II

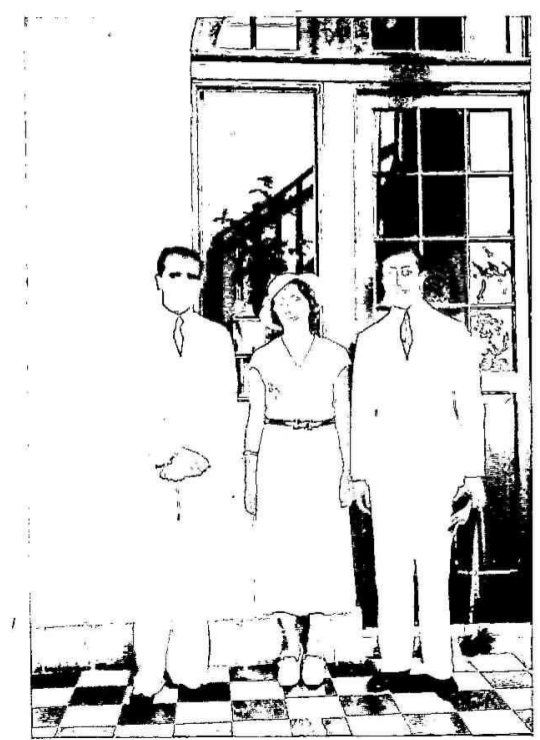

At the Phytopathological Meeting: (Left) A. A. Bitancourt, who was elected president; (right) H. V. S. Grillo, Chairman of the organizing committee; (conter) Anna E. Jenkins. 
Archivos do Museu Nacional.
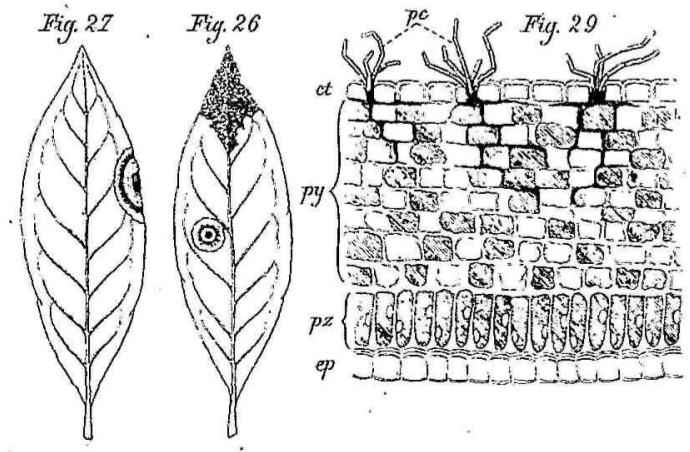

Corcospora coffeicola on coffee, after Goeldi (30). Legends as given by Goeldi:

Fig. 26. Coffee leaf, with two Ramularia spots, one in the center and the other at the extremity.

Fig. 27. Coffee leaf with a Ramularia spot in the margin (natural sizo),

Tig. 29. Vertical section through a Ramularia spot. The upper side of the drawing (lower of the leaf) shows the hyphae $(p c)$ bearing the conidia, projecting in tufts through the stomata. These tuits arise from a parent mycelium which extends between the cells of the parenchyma $(p y)$ to the interior of the leaf (Hartnack 3/7). 


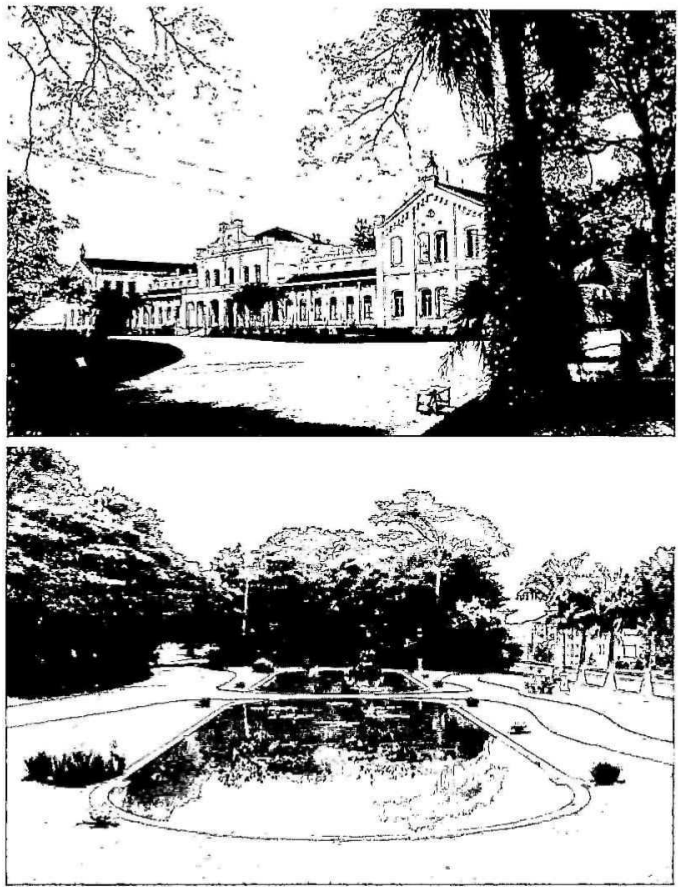

Views at the Agricultural College at Piracicaba, of which the campus, known as the English Park, was landsoapod by Puttemans. Photographs contributed (above) by Dr. Philippe Westin C. de Vasconcollos and (below) by Dr. A. P. Viégas. 


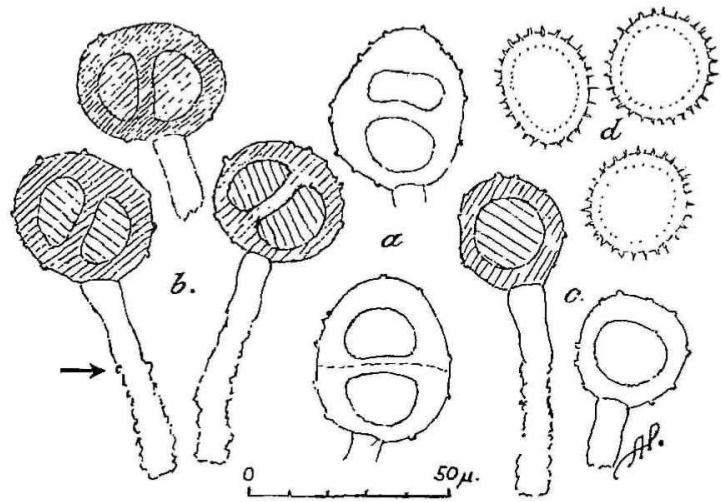

Puccinia justiciae Pultemans. After Puttemans (80). The legend reads as follows: "( $a$ ) Normal teleutospores; (b) teleutospores with pedical inserted obliquely; $(c)$ one-celled teleutospores; $(d)$ uredospores. Original figures by the author, enlarged from the natural 600 times." 


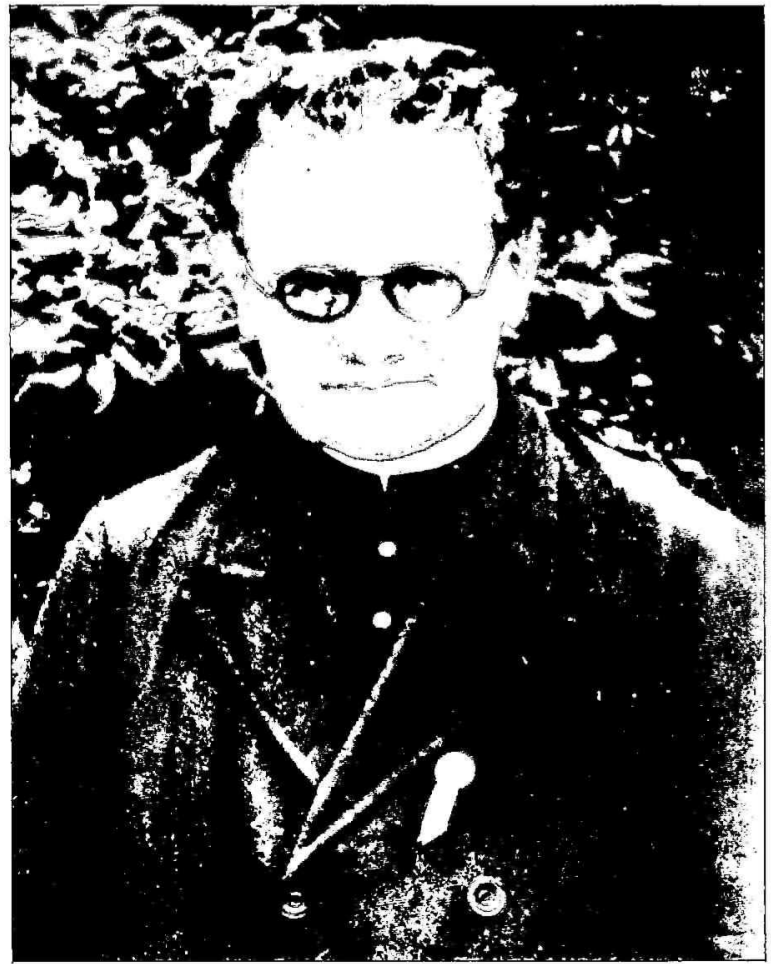

Rev. C. Torrend, photograph taken in the Botanical Garden at Rio de Janeiro in October 1893, while he was attending the first South American Congress of Botany as representative of the State of Bahia. 


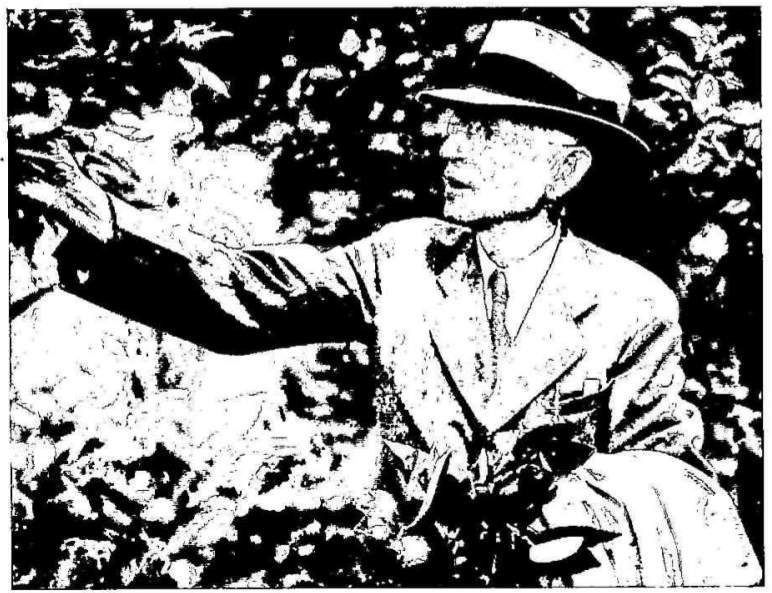

Professor H. S. Faweett in a grove of Bahía Navel oranges at Campinas, December 1936. Photograph by H. P. Krug. 


\section{PLATE VIII}

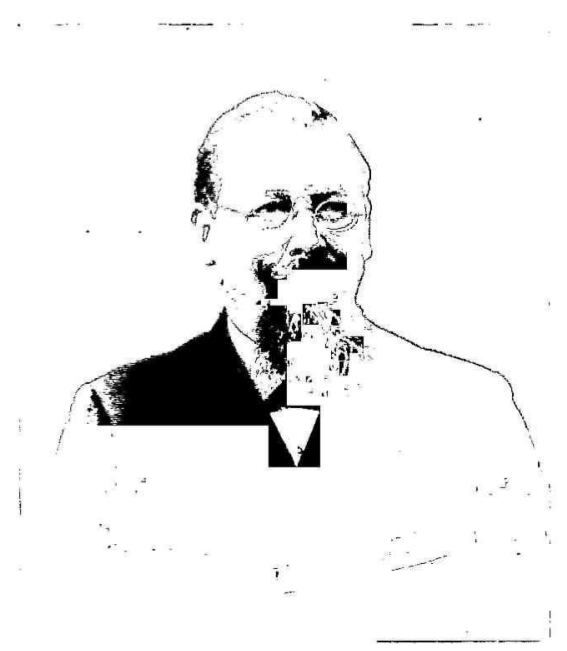

Emil A. Goeldi, after Howard (41) in Popular Science Monthly. 